\title{
Evaluation of Fenitrothion Resistance and Biochemical Mechanism in three Populations of Culex pipiens (Diptera: Culicidae) from Southern Tunisia
} Ahmed Tabbabi ${ }^{1 *}$, Jaber Daaboub ${ }^{1,2}$, Ali Laamari', Raja Ben Cheikh ${ }^{1}$ and Hassen Ben Cheikh ${ }^{1}$

${ }^{1}$ Laboratory of Genetics, Faculty of Medicine of Monastir, Monastir University, 5019, Monastir, Tunisia

${ }^{2}$ Department of Hygiene and Environmental Protection, Ministry of Public Health, 1006, Bab Saadoun, Tunis, Tunisia

\begin{abstract}
Evaluation of fenitrothion resistance was realized in three populations of Culex pipiens collected in Southern Tunisia between March 2002 and October 2005. It was not possible to considered bioassays tests to fenitrothion in sample \# 3 due to their control-level mortality. The RR50 were 27.1 in sample \# 1 and 179 in sample \# 2. All the studied samples showed the presence of one or more esterases in their electrophoretic profiles except the sample \# 3 which was sensitive to propoxur. The addition of $\mathrm{Pb}$ to fenitrothion bioassays indicated the involvement of CYTP450 in the recorded resistance. This result could be explained by the massive use of the permethrin in the control against these insects in southern Tunisia. We also showed that the resistance to fenitrothion was correlated with the propoxur resistance. These results indicate that modifications of the target, AChE1, can be involved in the recorded resistance.
\end{abstract}

Keywords: Culex pipiens; Resistance; Fenitrothion; Propoxur; Esterases; CYP450; AChE1; Southern Tunisia

\section{Introduction}

The resistance of pathogen vectors that cause human or animal diseases to insecticides affects both the economy and public health globally: it requires increasing the amount of used insecticides and developing new molecules or formulations (thus raising costs). It makes the available products and vector control strategies inefficient, thus leading to an increased prevalence of the pathogens and diseases they transmit [1-3].

The resistance of a target species can be defined as an inheritance reduction of susceptibility to an insecticide [2]. At the fundamental level, this is an adaptation to the new environment selected by the pressure exerted by one or more insecticides, according to a natural selection process. Resistant individuals carry one or more gene mutations (known as resistance alleles) encoding proteins that interact with the insecticide. Thus, the mutated proteins prevent the insecticide from reaching its target, for example by degrading it, or by modifying this target allowing the insects carrying these mutations to survive doses of insecticide normally lethal [4-11].

For years, the organophosphates (OPs) and synthetic pyrethroids have been widely used in the mosquito control programs. Currently, in addition to pyrethroid insecticides (permethrin and deltamethnin), many OPs including fenitrothion insecticide were largely used in Culex pipiens control.

This study reported the resistance of Culex pipiens to fenitrothion (OP). The aim is to present the main mechanisms of resistance to fenitrothion as well as the current situation in terms of resistance to this insecticide.

\section{Materials and Methods}

\section{Mosquito strains}

Six strains of mosquitoes were used in this study: three field populations of Culex pipiens collected in Southern Tunisia between March 2002 and October 2005 (Table 1 and Figure 1), S-Lab reference used as sensitive strain, SA2 and SA5 with overproduced esterases A2$\mathrm{B} 2$ and A5-B5, respectively.

\section{Insecticides and synergists}

Two insecticides were used for bioassays: the organophosphate fenitrothion (98.5\% [AI]), brought from laboratory Dr Ehrenstorfer,

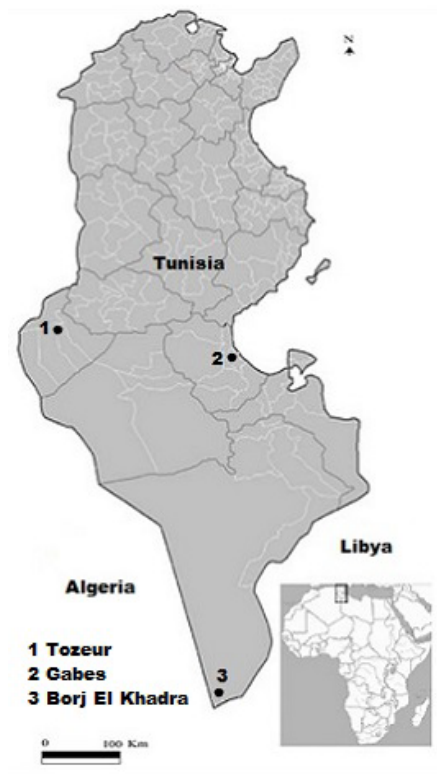

Figure 1: Geographic origin of Tunisian populations.

Germany) and the carbamate propoxur (99.9\% [AI], Bayer AG, Leverkusen, Germany). Two synergists were used to help detect detoxification enzymes involved in resistance: S,S,S tributyl phosphorothioate (DEF), an esterase inhibitor, and piperonyl butoxide (PB), an inhibitor of mixed function oxidases.

\section{Bioassay procedures}

We used standard methods to do bioassays tests [12,13]. Data

*Corresponding author: Tabbabi A, Laboratory of Genetics, Faculty of Medicine of Monastir, Monastir University, 5019, Monastir, Tunisia, Tel: 0021697085424 Fax: 73460737; E-mail: tabbabiahmed@gmail.com

Received May 04, 2017; Accepted May 18, 2017; Published May 25, 2017

Citation: Tabbabi A, Daaboub J, Laamari A, Ben Cheikh R, Ben Cheikh H (2017) Evaluation of Fenitrothion Resistance and Biochemical Mechanism in three Populations of Culex pipiens (Diptera: Culicidae) from Southern Tunisia. Hereditary Genet 6: 178, doi:10.4172/2161-1041.1000178

Copyright: (c) 2017 Tabbabi A, et al. This is an open-access article distributed under the terms of the Creative Commons Attribution License, which permits unrestricted use, distribution, and reproduction in any medium, provided the original author and source are credited. 
Citation: Tabbabi A, Daaboub J, Laamari A, Ben Cheikh R, Ben Cheikh H (2017) Evaluation of Fenitrothion Resistance and Biochemical Mechanism in three Populations of Culex pipiens (Diptera: Culicidae) from Southern Tunisia. Hereditary Genet 6: 178. doi:10.4172/2161-1041.1000178

Page 2 of 3

\begin{tabular}{|c|c|c|c|c|}
\hline Code & Locality & Breeding site & $\begin{array}{c}\text { Date of } \\
\text { collection }\end{array}$ & $\begin{array}{c}\text { Mosquito control (used insecticides) } \\
\text { control }\end{array}$ \\
\hline 1 & Tozeur & Ditch & Oct. 2005 & Frequent (C, Pm, F, P, D) \\
\hline 2 & Gabes & Drain & June 2005 & Frequent (C, Pm, P, D) \\
\hline 3 & Borj El-Khadra & Water pond & Mar 2002 & Occasional (P) \\
\hline C: Chlorpyrifos ; T: Temephos ; Pm: Pirimiphos methyl ; F: Fenitrithion ; P: Permethrin ; D: Deltamethrin \\
\hline
\end{tabular}

Table 1: Geographic origin of Tunisian populations, breeding site characteristics and insecticide control.

\begin{tabular}{|c|c|c|c|c|c|c|c|c|c|c|c|c|c|}
\hline \multirow[b]{2}{*}{ Population } & \multicolumn{3}{|c|}{ Fenitrothion } & \multicolumn{5}{|c|}{ Fenitrothion +DEF } & \multicolumn{5}{|c|}{ Fenitrothion $+\mathrm{Pb}$} \\
\hline & $\begin{array}{l}\mathrm{LC}_{50} \text { in } \\
\mu \mathrm{g} / \mathrm{l} \text { (a) }\end{array}$ & $\begin{array}{l}\text { Slope } \\
\pm \text { SE }\end{array}$ & $\begin{array}{l}\mathrm{RR}_{50} \\
\text { (a) }\end{array}$ & $\begin{array}{l}\mathrm{LC}_{50} \text { in } \\
\mu \mathrm{g} / \mathrm{l} \text { (a) }\end{array}$ & $\begin{array}{l}\text { Slope } \\
\pm \text { SE }\end{array}$ & $\begin{array}{l}\mathrm{RR}_{50} \\
\text { (a) }\end{array}$ & $\begin{array}{l}\mathrm{SR}_{50} \\
\text { (a) }\end{array}$ & RSR & $\begin{array}{l}L C_{50} \text { in } \\
\mu g / l(a)\end{array}$ & $\begin{array}{l}\text { Slope } \\
\pm \text { SE }\end{array}$ & $\mathrm{RR}_{50}$ (a) & $\mathrm{SR}_{50}(\mathrm{a})$ & RSR \\
\hline S-Lab & $\begin{array}{c}3.3 \\
(1.7-6.3)\end{array}$ & $\begin{array}{c}3.19 \\
\pm 0.94\end{array}$ & - & $\begin{array}{c}1.3(1.0- \\
1.6)\end{array}$ & $\begin{array}{c}2.43 \\
\pm 0.26\end{array}$ & - & $\begin{array}{c}2.5 \\
(1.2-5.2)\end{array}$ & - & $\begin{array}{c}2.8 \\
(0.18-44)\end{array}$ & $\begin{array}{l}1.44 \\
\pm 0.93\end{array}$ & - & $\begin{array}{c}1.1 \\
(0.34-3.9)\end{array}$ & - \\
\hline 1-Tozeur & $\begin{array}{c}91 \\
(47-179)\end{array}$ & $\begin{array}{c}1.31 \\
\pm 0.17\end{array}$ & $\begin{array}{c}27.1 \\
(12.9-56.8)\end{array}$ & $\begin{array}{c}10 \\
(5.0-21)\end{array}$ & $\begin{array}{c}1.01 \\
\pm 0.14\end{array}$ & $\begin{array}{c}7.7 \\
(5.3-11.2)\end{array}$ & $\begin{array}{c}8.8 \\
(5.9-12.9)\end{array}$ & 3.5 & $\begin{array}{c}3.6 \\
(0.61-21)\end{array}$ & $\begin{array}{c}1.31 \\
\pm 0.45\end{array}$ & $\begin{array}{c}1.2 \\
(0.35-4.6)\end{array}$ & $\begin{array}{c}24.6 \\
(10.8-56.0)\end{array}$ & 21.3 \\
\hline 2-Gabès & $\begin{array}{c}601 \\
(488-738)\end{array}$ & $\begin{array}{c}3.4 \\
\pm 0.59\end{array}$ & $\begin{array}{c}179 \\
(89.5-359)\end{array}$ & $\begin{array}{c}601 \\
(488-738)\end{array}$ & $\begin{array}{c}3.40 \\
\pm 0.59\end{array}$ & $\begin{array}{c}451 \\
(310-654)\end{array}$ & $\begin{array}{c}1.0 \\
(0.69-1.4)\end{array}$ & 0.40 & $\begin{array}{c}367 \\
(238-564)\end{array}$ & $\begin{array}{c}5.06 \\
\pm 1.76\end{array}$ & $\begin{array}{c}127 \\
(36.2-446)\end{array}$ & $\begin{array}{c}1.6 \\
(0.78-3.4)\end{array}$ & 1.4 \\
\hline
\end{tabular}

(a) $95 \% \mathrm{Cl}$

RR50: Resistance Ratio at LC50 (RR50=LC50 of the population considered / LC50 of Slab); SR50, synergism ratio (LC50 observed in absence of synergist / LC50 observed in presence of synergist). RR and SR considered significant $(\mathrm{P}<0.05)$ if their $95 \% \mathrm{Cl}$ did not include the value 1.

RSR: Relative Synergism Ratio (RR for insecticide alone / RR for insecticide plus synergist).

Table 2: Fenitrothion resistance characteristics of Tunisian Culex pipiens in presence and absence of synergists $\mathrm{DEF}$ and $\mathrm{Pb}$.

were analyzed by probit analysis [14] using a BASIC program [15]. We calculated the resistance ratios at the median lethal concentration (LC50) and LC95 by comparing the lethal concentration values of field populations and S-Lab strain. Synergism tests were similar to the bioassay tests except that $0.5 \mathrm{ml}$ of the desired concentration of synergist was added four hours before adding the concentration of insecticide to each cup.

\section{Esterase assay}

Total esterase activity in individual, frozen adult mosquitoes from field populations was determined by starch electrophoresis according to the method of Pasteur et al. $[16,17]$.

\section{Results}

\section{Fenitrothion resistance}

The linearity of the dose-mortality response was accepted $(\mathrm{p}<0.05)$ just for S-Lab. It was not possible to considered bioassays tests to fenitrothion in sample \# 3 due to their control-level mortality. The RR50 were 27.1 in sample \# 1 and 179 in sample \# 2.

The additions of DEF to fenitrothion bioassays indicate that the increased detoxification by the EST (and/or GST) played only a minor role in the resistance in samples \# 1 . In fact, The SR was significantly higher than that recorded in S-Lab in samples \# 1 which showed RR50 $>1$ in the presence of DEF. The tolerance was not decreased after addition of DEF in sample \# 2 (Table 2 ). The $\mathrm{Pb}$ had not a significant effect on the fenitrothion resistance in S-Lab (SR50 $=1.16, \mathrm{p}<0.05)$. The SR50 was significantly higher than that recorded in S-Lab only in samples \# 1 (Table 2). The addition of $\mathrm{Pb}$ to fenitrothion bioassays eliminated completely the resistance of sample \# 1 (RR50=1.2, $\mathrm{p}>0.05$, $\mathrm{RSR}=21.3$ ), indicating that the resistance mechanisms in this sample were inhibited by $\mathrm{Pb}$.

\section{Cross-resistance of fenirtothion/propoxur}

Mortality caused by propoxur ranged from $1 \%$ in samples \# 2 which has the highest resistance rate to fenitrothion to $100 \%$ in samples \# 3 which was sensitive. Significant correlation was recorded between mortality due to propoxur and the LC50 of fenitrothion (Spearman rank correlation, $(r)=-0.69(\mathrm{P}<0.01))$. This was expressed by a percentage of $41 \%$ in samples \# 1 which had a medium rate of resistance.

\section{Esterase's activities}

All the studied samples showed the presence of one or more esterases in their electrophoretic profiles except the sample \# 3 which was sensitive: A4-B4 (and / or A5-B5) which had the highest frequency (59\%), C1 (28\%), A2-B2 (11\%), and B12 (3\%).

\section{Discussion}

Its lack of selectivity towards non-target wildlife combined with a probable risk of toxicity to humans has prevented its use on a larger scale. High resistance levels were demonstrated by our two studied samples. Moderate resistance has been detected in Brazil in some wild populations of Aedes aegypti by Macoris et al. Similarly, resistances have been found on Aedes aegypti against OPs, including fenitrothion in many Caribbean islands [18]. Hidayati et al. [19] showed that level of resistance to fenitrothion could be the result of repetitive exposure with malathion which is the same insecticide class. Similar results were recorded by Corena et al. [20] who reported a cross-resistance to temephos and three other OPs insecticides (fenitrothion, fenthion and malathion).

Observation of insecticide resistance in a vector population is not necessarily associated with treatment failures. Indeed, the resistance must be widely distributed among the target population in order to have a visible operational impact. In addition, some insecticides have, in addition to their lethal action, a repellent action. For permethrin, for example, the major effect of which is repulsion, resistance can have only a limited effect on the overall effectiveness of the intervention. However, it is essential to detect as soon as possible the appearance of resistance, in order to allow operators to adapt their control strategy.

Our study detected many esterases probably involved in the recorded resistance to fenitrothion (OP). The involvement of these enzymes in the OPs resistance was confirmed on Culex pipiens and other insects species by many previous studies [5,21-23]. Esterase's activities showed the implication of many esterases in resistance of studied populations. However, many previous studies observed elevated esterase levels, but found no correlation with resistance [24-29].

The addition of $\mathrm{Pb}$ to fenitrothion bioassays indicated the involvement of CYP450 in the recorded resistance. This result could be explained by the massive use of the permethrine in the control 
against these insects (Table 1). Our study is in agreement with previous publication on correlation between cytochrome P450 enzymes and resistance to pyrethroids [30]. Multidisciplinary insect resistance studies are needed to determine how resistance to an insecticide may develop after exposure to another family of pesticides, and whether complementarities exist between these mechanisms of detoxification.

We also showed that the resistance to fenitrothion was correlated with the propoxur resistance. These results indicate that modifications of the target can be involved in the recorded resistance. The involvement of AChE1 in OPs insecticides was confirmed in several mosquito species [31].

\section{Acknowledgements}

This work was kindly supported by the Ministry of Higher Education and Scientific Research of Tunisia by funds allocated to the Research Unit (Génétique 02/UR/08-03) and by DHMPE of the Minister of Public Health of Tunisia. We are very grateful to $S$. Ouanes, for technical assistance, A. Ben Haj Ayed and I. Mkada for help in bioassays, S. Saïdi, Tunisian hygienist technicians for help in mosquito collecting, and M. Nedhif and M. Rebhi for their kind interest and help.

\section{References}

1. Georghiou GP, Lagunes-Tejeda A (1991) The occurrence of resistance to pesticides in arthropods. Food and Agriculture Organization, Rome.

2. Nauen R (2007) Insecticide resistance in disease vectors of public health importance. Pest Manag Sci, 63: 628-633.

3. Whalon ME, Mota-Sanchez D, Hollingworth RM (2008) Global pesticide resistance in arthropods. 169 pp. Oxford University Press, Oxford, UK.

4. Weill M, Lutfalla G, Mogensen K, Chandre F, Berthomieu A, et al. (2003) Insecticide resistance in mosquito vectors. Nature (Lond.) 423: 136-137.

5. Hemingway J, Hawkes N, McCarroll I, Ranson H (2004) The molecular basis of insecticide resistance in mosquitoes. Insect Biochem Mol Biol 34: 653-665.

6. Russel RJ, Claudianos C, Campbell PM, Horne I, Sutherland TD, et al (2004) Two major classes of target site insensitivity mutations confer resistance to organophosphate and carbamate insecticides. Pestic Biochem physiol 79: 84-93.

7. Alout $H$, Berthomieu A, Hadjivassilis A, Weill M (2007) A new amino-acid substitution in acetylcholinesterase 1 confers insecticide resistance to Culex pipiens mosquitoes from Cyprus. Insect Biochem. Mol. Biol 37: 41-47.

8. Rooker S, Guillemaud T, Berge J, Pasteur N, Raymond M (1996) Coamplification of esterase $A$ and $B$ genes as a single unit in Culex pipiens mosquitoes. Heredity 77 : 555-561.

9. Hemingway J, Hawkes N, Prapanthadara L, Jayawardenal KG, Ranson H (1998) The role of gene splicing, gene amplification and regulation in mosquito insecticide resistance. Phil Trans R Soc Lond B Biol Sci 353: 1695-1699.

10. Karunarathne $\mathrm{SH}$, Hemingway J (2001) Malathion resistance and prevalence of the malathion carboxylesterase mechanism in populations of mosquito vectors of disease in Sri Lanka. Bull World Health Organization 79: 1060-1064.

11. Ranson H, Claudianos C, Ortelli F, Abgrall C, Hemingway J, et al. (2002) Evolution of supergene families associated with insecticide resistance. Science, Washington, DC. 298: 179-181.

12. Georghiou GP, Metcalf RL, Gidden FE (1966) Carbamate resistance in mosquitoes. Selection of Culex pipiens fatigans Wied for resistance to Baygon. Bull. Word Health Org 35: 691-708.

13. Georghiou GP, Wirth M, Tran H, Saume E, Knudsen AB (1987) Potential for organophosphate resistance in Aedes aegypti (Diptera: Culicidae) in the Caribbean and neighboring Countries, J. Med. Entomol 24: 290-294.

14. Finney DJ (1971) Probit analysis. Cambridge University Press, Cambridge, UK

15. Raymond M, Foumier D, Bergé JB, Cuany A, Bride JM, et al. (1985) Singlemosquito test to determine genotypes with an acetylcholinesterase insensitive to inhibition to propoxur insecticide. J. Am. Mosq. Control Assoc 1: 425-427.

16. Pasteur N, Iseki A, Georghiou GP (1981) Genetic and biochemical studies of the highly active esterases $A^{\prime}$ and $B$ associated with organophosphate resistance in mosquitoes of the Culex pipiens complex. Biochemical Genetics 19: 909-919.

17. Pasteur N, Pasteur G, Bonhomme F, Britton- Davidian J (1988) Practical isozyme genetics. Ellis Horwood, Chichester, UK.

18. Rawlins SC, Ragoonansingh R (1990) Comparative organophosphorous insecticide susceptibility in Caribbean population Aedes aegypti and Toxorynchites moctezuma. Journal of American Mosquito Control Association 6: 315-317.

19. Hidayati H, Nazni WA, Lee HL, Sofian-Azirun M (2011) Insecticide resistance development in Aedes aegypti upon selection pressure with malathion. Tropical Biomedicine 28: 425-437.

20. Corena M Del P, Seron TJ, Lehman HK, Ochrietor JD, Kohn A, et al. (2002) Carbonic anhydrase in the midgut of larval Aedes aegypti: cloning, localization and inhibition. J. Exp. Biol 205: 591-602.

21. Ben Cheikh H, Haouas-Ben Ali Z, Marquine M, Pasteur N (1998) Resistance to organophosphorus and pyrethroid insecticides in Culex pipiens (Diptera: Culicidae) from Tunisia. J Med Entomol 35: 251-260.

22. Liu H, Xu Q, Zhang L, Liu N (2005) Chlorpyrifos resistance in mosquito Culex quinquefasciatus. J. Med. Entomol 42: 815-820.

23. Huang HS, Hu NT, Yao YE, Wu CY, Chiang SW, et al. (1998) Molecula cloning and heterologous expression of a glutathione-s-tranferase involved in insecticide resistance from the diamondback moth Plutella xylostella. Insect Biochem Mol Biol 28: 651-658.

24. Curtis CF, Pasteur N (1981) Organophosphate resistance in vecto populations of the complex Culex pipiens L. (Diptera, Culicidae). Bull Entomol Res 1: 153-161.

25. Fournier D, Bride J, Mouches C, Raymond M, Magnin M, et al. (1987) Biochemical characterization of the esterases $A 1$ and 81 associated with organophosphate resistance in the Culex pipiens L. complex. Pestic. Biochem. Physiol 27: 21L-217.

26. Villani F, White GB, Curtis CF, Miles CF (1983) Inheritance and activity of some esterases associated with organophosphate resistance in mosquitoes of the complex Culex pipiens L. (Diptera: Culicidae). Bull Entomol Res 73: 153-160.

27. Hemingway $J(1982)$ The biochemical nature of malathion resistancei $n$ Arwpllehs steph ensfir om Pakistan. Pestic Biochem Physiol 1: 149-151.

28. Hemingway J (1983) The biochemical nature of malathion resistance in Arwptteles arabier is from Sudan. Tr R Soc Trop Tvted Uyg 77: 477-480.

29. Hemingway J, Jayawardena KGI, Herath PRJ (1986) Pesticide resistance mechanisms produced by field selection pressures on Arnphebs nigerrimus and A. cdicifocres in Sri Lanka. Bull. WHO, Geneva 6: 753-758.

30. Wan-Norafikah O, Nazni WA, Lee HL, Zainol-Ariffin P, Sofian-Azirun M (2010) Permethrin resistance in Aedes aegypti (Linnaeus) collected from Kuala Lumpur, Malaysia. J Asia-Pacific Entomol 13: 175-182.

31. Labbé P, Berthomieu A, Berticat C, Alout H, Raymond M, et al. (2007) Independent duplications of the acetylcholinesterase gene conferring insecticide resistance in the mosquito Culex pipiens. Mol. Biol. Evol 24 1056-1067. 